\title{
GERMANY AFTER WORLD WAR II - CRUCIAL FRONTLINE OF INTELLIGENCE SERVICES WAR
}

The victorious allied countries divided Europe into parts after the end of World War II. This caused defeated Germany to become a point of contact between the two great ideological blocs. On both sides of the so-called Iron Curtain enormous land army units were placed, together with aircraft military groups and naval ships. The most important everyday mission performed on the border between the cold and the hot war was, however, the one fulfilled by forces which belonged to a less visible but still extremely important formation - namely the Intelligence Services, Counter-intelligence Services and, above all, their agents and analysts. While a cold-war tension was rising and the two German states were built, a territory of the current Federal Republic of Germany turned into one of the biggest fronts of world espionage. Divided Germany was a witness not only of a game led by the two biggest American and Soviet Intelligence Services, which was of the greatest importance from a global point of view, but also witnessed many minor clashes of other Intelligence Agencies. Germany's major focus fell mainly on offensive intelligence actions but defensive Counter-intelligence Services were also an important object of Germany's attention.

An icon of Cold War espionage was Berlin, a divided into four occupation zones city situated in East Germany and governed by the former allied powers. Berlin-based operations were multidimensional, since infiltration and intelligence actions encompassed all areas of functioning of the two German states. Besides, other countries whose military, political and economic interests were in close connection with Germany were also a subject of intelligence activities. What formed a basis for these actions was undoubtedly military espionage, directed on collecting new data pertaining to military potential of a possible enemy, who could gather on the most important arena of European politics. When a spectre of a regular war was pushed away, politically-focused espionage gained in significance. At a later time more focus was given also to economic espionage, mainly because of a rapid development of West German industry. Apart from the aforementioned fields of intelligence craftsmanship, both the Federal Republic of Germany (FRG) and the German Democratic Republic (GDR) were arenas of many unconventional actions which nowadays can be observed e.g. in Afghanistan or some African regions. The then spies and spies-catchers were given a free hand in plenty of cases. Today, after the German reunification into a single national being and Germany taking the lead in the European Union, one may assume that this kind of intelligence activities has weakened. Such a thesis is not valid, however, since new information, important for the Germany's national interest, concerning new threats with regard to intelligence and counter-intelligence have been coming to the surface. 
Therefore, the aim of this paper is to outline major fields of a war or, more precisely, many individual wars between Intelligence and Counter-intelligence Services which are connected with Germany, either in a territorial or an institutional way. At the same time, possible threats and challenges posed to German Intelligence and Counter-intelligence Services at the beginning of the $20^{\text {th }}$ century will be presented.

What needs to be emphasised first are, however, difficulties in a process of collecting necessary data. This stems from a fact that the majority of official documents pertaining to intelligence and counter-intelligence activities is secret in character. Even after a long period of time, these documents have not yet been made fully public, since many methods and solutions applied in the past have been, despite technological progress, used until now. What is more, publically available materials need to be critically assessed, since their primary aim may be, and undoubtedly usually is, to misinform potential enemies. A significant contribution to understanding of a cold-war clash of Intelligence Services on a German front was brought by a disclosure of East Germany materials of Ministerium für Staatssicherheit, MfS. ${ }^{1}$

\section{ESPIONAGE - GENERAL CHARACTERISTICS OF THE TOPIC}

The very notion of intelligence actions, in relations not only between nations and states but also in business, is nothing new and did not emerge along with the Cold War. Needless to say that, since the Ancient Times, espionage has been perceived as a natural element in world's functioning processes. This element was rather hidden though; it belonged more to the seamy side of life. It is also difficult to pinpoint the very moment in history which can be regarded as a beginning of espionage, since in many ancient cultures one can find treatises, books and legends full of descriptions of intelligence and espionage actions of various types. It is enough to mention that the Bible contains an entire excerpt about the actions taken by complex spy rings. In a biblical context the most telling is a case of activities fulfilled by order of Joshua. It is exactly in the Book of Joshua where one can read that "Joshua, son of Nun secretly sent two spies from Shittim. «Go, look over the land», he said, «especially Jericho»". ${ }^{2}$ The clearest example of a role of espionage comes, however, from Asia. The case of the ancient China is the one which, in fact, has still remained valid. A Chinese sage and a military mandarin Sun Tzu, considered one of the fathers of a tactical and strategic thought, addressed in his treatise "The Art of War" some problematic issues concerning the employment of spies. Sun Tzu wrote: "Wise rulers and capable commanders win because they have advance information about the enemy. Such fore-knowledge cannot be obtained from ghosts and spirits, cannot be had from analogous experiences, cannot be found by calculating the positions of the sun, the moon and stare. It must be obtained from the people who clearly know the enemy's situations". ${ }^{3}$ At the same time Sun Tzu described five kinds

1 We can see that the activity of the Special Services (for example Stasi) are later stimulating mass culture. See: B. F. Woods, A Political History of Espionage Fiction, New York 2009.

2 The Book of Joshua 2:1, Pismo Święte Stary i Nowy Testament, Poznań 2006, p. 249.

3 Sun Tzu, Sztuka wojny, in: Sztuka Wojny, Sun Tzu, Sun Pin, Gliwice 2004, p. 134. 
of spies: local spies, internal spies, double spies, dead spies, and living spies. The so-called local spies are recruited from the inhabitants of a particular territory. Their major advantage is a capability of an easy and natural melting into an infiltrated community. Sun Tzu considers local spies capable of deep infiltration of a local population by means of gathering informers and spies to spy on broadly understood decisive circles of a chosen target. Of course, a category of a double spy concerns a re-recruitment process of an agent who was originally sent by an enemy. In this case, it is important to stress a possibility that, apart from a simple re-recruitment, complex actions may occur. Then, a re-recruited agent is once again re-recruited. Dead spies are, in a contemporary understanding, counterfeit personal sources of information for an enemy. Their aim is to establish a relation and to co-operate with a hostile intelligence or counter-intelligence services in order to conduct disinformation operations. ${ }^{4}$ Living spies are, in fact, typical operational agents who are able to pass a message obtained in a hostile territory to their own intelligence centre.

When considering a role of intelligence in the contemporary world one must admit that it is a constant process of collecting information, often secret in character, by means of various methods, by both national and non-national subjects. Espionage is, in turn, a very activity implemented by espionage agencies. Intelligence means not only collecting data; it means also to analyse and to process collected data into an intelligence assessment necessary for politicians, military men, and scientists. Intelligence is also an attempt to create a stable system of a backstage shaping of the environment in order to complete one's own goals. However, apart from a direction to collect data, an intelligence process is connected also with a direction to misinform, so to send counterfeit or partially counterfeit messages in order to weaken capacity of a potential enemy. Intelligence always encounters its enemy in the form of counter-intelligence. Therefore, individual countries or even larger business structures, e.g. international corporations, develop right since the beginning not only their own intelligence cells but also defensive counter-intelligence cells. There are many modes of categorisation and classification of intelligence or, to narrow the scope, espionage. The most widely known is the one based on a sources of information. Then one can use a notion of so-called white intelligence, based on publically available information and official sources, e. g. newspapers, declassified documents, television, radio, and contemporary also social networking sites or, generally speaking, the Internet. Apart from white intelligence one can also distinguish grey intelligence, operating at the meeting point of public and secret information, with the latter collected against the will of a spied-on subject. The most recognisable type of intelligence is so-called black intelligence, based on a process of stealing information and collecting data in an illegal way. There is a rule saying that both enemies and allies spy on each other. What is more, espionage as a process is not a procedure activated only in the periods of danger. It rather operates all the time in order to foresee possible crises. Apart from black, grey and white intelligence one should mention a important division into the so-called HUMINT, SIGINT, TECHINT, and TELINT. HUMINT ${ }^{5}$ is a type of personal intelligence which can be described as the

4 See: M. J. Manning, Disinformation, in: Encyclopedia of Espionage, Intelligence, and Security, Vol. I, (eds.) K. L. Lerner, B. W. Lerner, Detroit 2004, pp. 331-335.

5 N. Polmar, T. B. Allen, Księga szpiegów, Warszawa 2000, p. 257. 
most primitive form of human intelligence activities. SIGINT ${ }^{6}$ is a type of intelligence based on monitoring the collected material and data about technologies an enemy has at his disposal. Today, a scope of operations led by TECHINT ${ }^{7}$ has been widened because of a development in digital and satellite technologies. TELINT ${ }^{8}$ is, in fact, a subtype of TECHINT, focused particularly on collecting and analysing foreign telemetric data. One can distinguish also a political, military and industrial intelligence. What needs to be stated, however, is the fact that nowadays the borders between intelligence activities both strictly political or strictly industrial in type have become blurred. To conclude, intelligence is a phenomenon which functions steadily in the contemporary world. It is a complex form of investigating aims and capabilities of potential enemies, non-aligned subjects, and allies.

\section{THE BEGINNING OF THE COLD WAR -GERMANY AS A SUBJECT}

The last days of World War II and the initial months after its end were, for a territory of the defeated Third Reich, a time of violent, often even brutal clashes of various intelligence forces. The major role in these strive was played by the special units of Soviet Counter-intelligence Military Services called Spiecjalnyje Mietody Rozobłaczenija Szpionow - better known as SMIERSZ, the units of Soviet Intelligence Services Narodny komissariat vnutrennikh del NKWD ${ }^{9}$ the special units of American Office of Strategic Services (OSS) ${ }^{10}$ the British units of Special Operations Executive (SOE). The aim of the intelligence and counter-intelligence activities on German territories occupied by the Allies was to gather people and collect scientific and technical infrastructure. The major stress was put on highly developed technologies of the German V-1 missiles or the first ballistic missiles V-2. However, German achievements in a field of jet-powered and rocket-powered engines, as well as submarines, including the biggest U-Boots, e.g. type IX D, were no less important. Intelligence Services competed with each other also in a task to regain the precious Nazi spoils of war: gold and artwork collections. Of course, catching important German officers and dignitaries by the allied intelligence forces was a very foundation for this process. It is justified to assume that the aforementioned activities were not always strictly connected with catching Nazi war criminals, since more precious seemed either engineers or former Abwehra's agents, Sicherheitsdienst SD's agents or Gestapo. The activities of the major allied Intelligence Services were interrupted by the activities of the German spy and intelligence rings, whose major aim was, in a face of a fall of the Third Reich, to protect the former Nazi establishment members and their evacuation to safe countries, mainly located in South America. These missions were fulfilled, among others, by a famous Organisation Der

6 Ibidem, p. 637.

7 Ibidem, p. 646.

8 Ibidem.

9 See: J. E. Haynes, H. Klehr, Historians, Communism \& Espionage, San Francisco 2003.

10 Before 1947 and the beginning of functioning of the modern CIA, there was also World War II Office of Strategic Services (OSS) and later Central Intelligence Group (CIG). See: E. Liptak, Office of Strategic Services 1942-1945, New York 2009. 
Ehemaligen SS Angehörigen, known as ODESSA. ${ }^{11}$ However, when the first period of heavy pillage of the remnants of Nazi science and industry ended, and hostility among the former Allies rose, the first signals of a change in a focus of the intelligence activities emerged. When the Central Intelligence Agency, abbr. CIA ${ }^{12}$ was founded, the whole of forces and means was concentrated on a major intelligence front located territorially on the occupied German areas. On both sides there were the aforementioned CIA and its Soviet counterpart, NKWD (after 1954 the KGB, Komitiet gosudarstwiennoj biezopasnosti pri Sowietie Ministrow $S S S R^{13}$ ). Support to both sides located on territories of a later East and West Germany was given by Intelligence Services of other allied countries. Thus, the presence of the British MI- $6^{14}$ and French SDECE (Service de Documentation Exterieure et de Contre-espionnage), both in GDR and in FRG, was justified. The aims of intelligence and spy activities on a territory of divided Germany included basic observation of a military activity of here gathered army forces, either communistic or belonging to NATO. That was quite a strategic type of an activity, since both sides, in the face of a conflict between East and West, regarded Europe and the territory of divided Germany as a potential major front in a case of a full scale conflict. This was closely connected with a process of collecting data concerning a level of training of necessary army units, their dislocation, places of collecting materials to meet the need of a full quality logistic service. Another vital aim was to collect information about the latest types of armaments and weapons, delegated by both sides to quasi-front units stationing in GDR and FRG. Such activities were fulfilled by both civil Intelligence Services and army intelligence formations. In the analysis of the activities directed on an examination of a defensive potential of both sides, one can find in interesting that a common phenomenon was to accept, almost throughout the period of the Cold War, the so-called Potsdam Missions, which were de facto a legalised form of espionage. At the same time, both sides were striving for a recruitment of civil agents whose main advantage was an access to information in the field of policies pursued by a hostile side. To make such spy activities easier, a not completely guarded border between East and West Germany, as well as a division of Berlin into occupation areas were destined. It was only after a foundation of a Berlin Wall when a steady infiltration was broken, also thanks to successful process of sealing the borders conducted by German border services appointed to this task by all forces sharing the borderline. Divided Germany was a place of the most difficult spy operations for the major intelligence agencies in the world. On the one hand, making contact through Berlin was available, but on the other hand, Counter-intelligence Services were monitoring all the time, with all due intensity, a territory which could be potentially used for spy operations. What is more, after a further extension of GDR and FRG, the biggest possible amount of data about the capabilities of both German states had to be collected. Due to a dynamic de-

11 See: J. S. Craig, Peculiar Liaisons In War, Espionage, and Terrorism in the Twentieth Century, New York 2005, pp. 168-196.

12 The new look on history of CIA see: T. Weiner, Legacy of Ashes. The History of the CIA, London 2007.

13 See: C. Andrew, V. Mitrokhin, The Sword and the Shield. The Mitrokhin Archive and the Secret History of the $K G B$, New York 1999.

14 See: P. Davies, MI6 and the Machinery of Spying, London 2004. 
velopment of FRG, especially with regard to economy and new innovative technologies, a branch of industrial intelligence was activated. Until the end of The Cold War, the CIA and the KGB/GRU had regarded their posts in GDR and FRG as a front ones. Thus, the best possible staff was delegated to serve there. When it comes to Berlin though, apart from Swiss or Finnish cities, Berlin was a very place considered a symbol of a war between Intelligence Services. ${ }^{15}$ Significantly enough, the territory of the two German states was classified as a area of a potential battlefield of World War III. Therefore, every piece of information about infrastructure, population, concentration of army forces etc. were considered vital, which further determined the intensity of intelligence and spy activities. An interesting case though, one of the most secret affairs in the age of the Cold War, was a process of creating a intelligence backroom and logistic bases on the territory of FRG by the KGB and the GRU agents. ${ }^{16}$ These bases were supposed to be used during redeployment of the Specnaz GRU and the KGB, whose soldiers underwent a set of preparation procedures concerning an attack on the key FRG and the United States' military, political and industrial installations, which were located in the West Germany. ${ }^{17}$ Their actions were supposed to be coordinated and supported by the KGB and GRU residents in FRG, both these official and these who operated in so-called illegal, so agents who had no diplomatic immunities. The Glienicke Bridge in Berlin became, so to speak, a symbol of spy wars led on the German territory. It was a very place where many exchanges of the captured spies took place. One of the most famous exchanges was completed in 1985, when Marian Zacharski and two other Eastern spies were exchanged for another 25 (!) people who fell under the interest of Western governments.

\section{THE NEW PLAYERS (BND, BFV AND MFS) - THE BEGINNINGS OF AN INDEPENDENT INTELLIGENCE COMMUNITY}

When the two German states were built, the new subjects in the international intelligence game were born on both sides of the so-called Iron Curtain. Two independent organizations were founded in FRG - an intelligence agency called the Federal Intelligence Service (Bundesnachrichtendienst, BND) ${ }^{18}$ and a counter-intelligence agency called The Federal Office for the Protection of the Constitution (Bundesamt für Verfassungsschutz, BfV).${ }^{19}$ The strongest position belonged to the BND formed exactly on April 1st, 1956. The foundations of the new West German Intelligence Services were laid by the United States of America. The CIA permitted further use of a spy ring of Maj. Gen. Reinhard Gehlen which comprised of agents re-recruited after World War II. Reinhard Gehlen ${ }^{20}$ himself had great spy and analytical experience,

\footnotetext{
15 See: Przewodnik KGB po miastach świata, (eds.) A. Uderzo, R. Goscinny, Warszawa 2001.

${ }_{16}$ Such an action mentioned for example in W. Suworow, Specnaz Historia sit specjalnych Armii Radzieckiej, Warszawa 2003, pp. 120-131.

17 About significant role of military intelligence in military operations see: R. Ferris, Intelligence and Strategy, London 2005, pp. 239-287.

${ }_{18}$ N. West, Historical Dictionary of International Intelligence, Toronto 2006, p. 41.

19 Ibidem, p. 40

20 See: CIA biographic Sketch on General Reinhard Gehlen, http://www.gwu.edu/ nsarchiv/ NSAEBB/NSAEBB138/CIA\%20Information\%20Act\%20-\%20Reinhard\%20Gehlen.pdf (26.06.2012).
} 
since he alone worked out the Soviet powers on The Eastern Front during World War II. ${ }^{21}$ After the fall of The Third Reich Gehlen skillfully ensured himself survival in post-war conditions, since all the data he had collected were made a bargaining counter in negotiations with the Western Allies. These materials, both in a form of data and in a form of intelligence contacts of Gehlen, were finally, after a year of a negotiating process, passed on to the American party. Besides, the American party allowed to form an independent Western Germany new intelligence agency, later called the Gehlen Organization. ${ }^{22}$ Its scope of activities was centred around surveillance of the eastern occupation area and collecting personal information sources from the eastern runaway groups. What is more, a group of sleeper agents previously operating on the territory of The Third Reich and the Soviet occupation zone was reactivated. The major task was to collect information about the armed forces of the USSR. The basic problem was in functioning of the Gehlen Organization was, however, natural reliance on a staff of the former Nazi Germany. The Organization was accused of possible concealment of the Nazi war criminals, coming either from Gestapo or from SD Intelligence Services, through their activation in spy activities for the USA. Besides, connections between the Gehlen Organization and the American Intelligence Services from 1946 to 1956 were an extremely controversial issue. At the very beginning, Gehlen and his spy rings were subordinate to the U.S. Army intelligence but when the CIA was formed in 1947 some competence frictions emerged. Since 1949 CIA had taken full control over the Gehlen Organization. What became a foundation for a new FRG - BND intelligence was the very Gehlen Organization. What also needs to be stated is the fact, that the BND took over even a headquarters of the Organization, located in a small village in Pullach, close to Munich. After its formation, the BND got subjugated directly to the post of the FRG Chancellor. This move was justified mainly by a close relationship between R. Gehlen and Konrad Adenauer. When it comes to an assessment of BND's efficiency in the period of The Cold War, opinions differ. What usually came to light were the situations unfavourable for the West Germany intelligence agencies. The most negative light was cast by cases of activities led by deep cover agents, in espionage jargon the so-called moles, who operated in trouble areas of the BND structures. One of such moles was, for example, Heinz Felfe, responsible for counter-intelligence activities in a Soviet direction, arrested in 1961 on a charge of espionage for USSR. ${ }^{23}$ Some opinions are voiced, e.g. among the former East German or Soviet agents, that a level of surveillance of the BND by eastern services was high. One can also assume that the CIA kept the BND under surveillance, using earlier supervision over the Gehlen Organization. To prove low effectiveness of the BND was also the fact that the organization did not gather any important personal information sources such as, for instance, Oleg Gordijewski ${ }^{24}$ (British intelligence) or Col. Ryszard Kukliński (American intelligence). At the same time,

21 See: C. Jörgensen, Hitler's Espionage Machine. German Intelligence agencies and operations during World War II, Staplehurst 2004.

22 See: R. Breitman, N. J. W. Goda, T. Naftali, R. Wolfe, U.S. Intelligence and the Nazis, Cambridge 2005, pp. 375-418.

${ }^{23}$ N. Polmar, T. B. Allen, Księga szpiegów, op. cit., p. 192.

24 See: O. Gordijewski, Ostatni przystanek - egzekucja, Warszawa 2001. 
a BND's counterpart in the East Germany could place the FRG Chancellor at a very top of a power hierarchy. Some limitations in the BND's activities were caused by competence disputes with the $\mathrm{BfV}$ counter-intelligence. The $\mathrm{BfV}$ was formed in the nineteen fifties and was based on a British counter-intelligence model. Similarly to the BND, the West German Counter-intelligence Sevices BfV were famous for their ineffective actions. The BfV frequently had to cover its scandalous mishaps or incompetent counter-intelligence control wielded over the most important state institutions. Obviously it is vital to stress that, unlike its counterpart in GDR, the BfV was forced to operate in an environment which was especially tough to lead counter-intelligence activities - the environment of a democratic country. ${ }^{25}$ However, only a mention about the most important cases which ended in defeat gives a picture of how poor was a FRG's counter-intelligence security status. In $1954 \mathrm{dr}$. Otto John, a former head of the FRG Counter-intelligence Services, got kidnapped or, in reality, re-recruited by the Stasi and the Soviet intelligence. Another well-know example of infiltration of the BfV by the West German intelligence was a case of Hans Joachim Tiedge. ${ }^{26}$ Tiedge was a member of a FRG's counter-intelligence from 1966 to 1985, the year when he fled to GDR and disclosed his activities in the agency and the cases of passing on secret information to the East German Intelligence Services. After 1990 it turned out that activities similar in kind to these fulfilled by Tiedge were performed by Klaus Kuron,${ }^{27}$ a person responsible in the BfV for a re-recruitment process of the East German spies. Apart from an obvious weakness proven by the example of infiltration of one's own structures, the BfV could not prevent hostile activities led against FRG's federal institutions. The most well-known scandal was an introduction of Günther Guillaume to a secretarial office of the Chancellor of the Federal Republic of Germany Willy Brandt by the Stasi ${ }^{28}$ However, one can also mention a case of Gabriele Gast, who was responsible for a preparation of intelligence data for the chancellor Helmut Kohl. A desertion of Tiedge was particularly painful for the West German intelligence community and this act fueled a process of changes in a structure and staff of the BND and the BfV. Apart from civil intelligence and counter-intelligence, right when the World War II ended and the new state was established, FRG was a territory to re-create the armed forces and military Intelligence Services in 1956-Amt für Nachrichtenwesen der Bundeswehr $(A N B w) .{ }^{29}$ To comment on the real activities of the ANBw and the effectiveness of this agency is barely possible, since even basic data is missing. What is more, the ANBw was concentrated on strictly military activities in order to compete with the BND and the BfV for influence. While assessing the BND's activities from the period of the Cold War one can assume that the West German intelligence was a weaker partner of the CIA or the MI6. However, it gave the FRG's authorities, the Chancellor in particular, a possibility to collect important data, especially on GDR level. There is also circumstantial evi-

25 See: D. Ganser, NATO's Secret Armies. Operation Gladio and Terrorism in Western Europe, New York 2005, pp. 189-211.

26 J. Adams, Historical Dictionary of German Intelligence, Toronto 2009, pp. 462-463.

27 Ibidem, p. 254.

28 G. Knopp, Elita szpiegów, Warszawa 2004, pp. 111-146.

29 J. Adams, Historical Dictionary of German Intelligence, op. cit., p. 302. 
dence that the BND was engaged in the activities covering some prominent former Nazis, hiding in South America. What is more, the BND quite possibly possessed a developed spy and informational net in the Middle East, at least at the beginning of its existence. Thus, one should assume that the BND had to cooperate in certain fields with the national intelligence agency of Israel called Mossad. These fields could include financial support or armament deliveries for Israel offered by the FRG (especially in between 1959-1967). Intelligence and Counter-intelligence Services from the GDR stood in complete contrast to the West German intelligence community. Ministerium für Staatssicherheit MfS, better known as the Stasi ${ }^{30}$ was a final effect of a strict supervision of the Soviet Intelligence Services. The Ministry for State Security of GDR - MfS, founded in April 1950, was supposed to fulfill both intelligence and counter-intelligence missions. ${ }^{31}$ The Ministry comprised of minor intelligence and police organizations, operating close to the Soviet structures. The first problems of MfS were closely intertwined with gathering suitable staff. Soviet founders favoured mainly agents who completed a training course in Soviet training centres. A so-called class criterion was also preserved. An example of the first Chekists, as the employees of the MfS called themselves, was Erich Mielke. ${ }^{32}$ It is important to mention, that army experience was acquired also by a group of the East German intelligence services officers, e.g. Ernst Wollweber, in the mission during the Spanish Civil War. However, also this time a part of the former Third Reich Intelligence Services staff was enlisted. While the GDR was developing, however, new staff was created, with better educated and better trained to a foreign intelligence service agents. A symbol of intelligence operations of the times became Markus Wolf. ${ }^{33}$ Wolf took a charge in a special MfS's foreign intelligence structure called Hauptverwaltung Aufklärung HVA. His work and activities which he supervised included concerned not only the FRG, but also the USA and other countries of the world. It can be stated that in every place where diplomatic posts of GDR were located, HVA's posts were located accordingly. The HVA's structures successfully infiltrated all FRG institutions and their biggest success was to introduce aforementioned Günther Guillaume in the closest decisive circle of Willy Brandt. ${ }^{34}$ Thanks to Guillaume's work as a secretary of the FRG Chancellor, the MfS not only collected secret data, but also enable the GDR authorities to properly pursue policies concerning relations with the FRG. The HVA was famous for its excellent training to gather personal information sources, e.g. during the Romeo operation, under which male agents were sent in order to seduce and recruit potentially important women working for the FRG. When the Cold War ended and Germany were reunited, the Federal Constitutional Court of Germany proclaimed, with a ratio of votes of 5 to 3, that supervision over intelligence activities against the West cannot constitute a ground for legal

${ }^{30}$ Stasi, in: Encyclopedia of Espionage, Intelligence, and Security, Vol. III, (eds.) K. L. Lerner, B. W. Lerner, Detroit 2004, pp. 114-115.

31 See: P. Maddrell, Spying on Science. Western Intelligence in Divided Germany 1945-1961, Oxford 2006.

${ }^{32}$ H. Schwan, Żywot w stużbie Stasi. Erich Mielke, Warszawa 2001.

33 E. Volkman, Spies: The Secret Agents Who Changed the Course of History, New York 1994, pp. $177-182$.

${ }^{34}$ G. Knopp, Elita szpiegów, op. cit., pp. 111-146. 
proceedings against the HVA agents. Effectiveness was decidedly a characteristics of the Stasi Counter-intelligence Services. The GDR was a police state, due to the fact of which all the activities performed by foreign Intelligence Services were strictly monitored. According to data available in "The Spy Book", short before the reunification, 90,000 full-time workers, both in civil and uniformed services, were employed by the Stasi. What is more, the Stasi developed an enormous, even when considering favourable conditions in Communist Bloc, net of agents and informers, comprising of, at a rough estimate, 170,000 members. Apart from sophisticated operations with personal sources, the MfS invested also in many various technological solutions connected with wiretap, bugging or radio watch devices. ${ }^{35}$ An interesting example of how the MfS controlled and infiltrated the society was a process of collecting scents and smells of dissidents and people suspected of hostile activities. Of course, unlike the HVA, after the reunification of Germany Counter-intelligence Services and the Security Services were struck by a wave of screening and a series of legal and court proceedings on a charge of illegal actions aimed at the opposition and the citizens suspected of anti-governmental actions. A great success of the FRG was, undoubtedly, gaining access to a vast array of files and records of the MfS and even recreation of the ones which were destroyed. To complete this task a special office was destined, called Bundesbeauftragte für die Unterlagern des Staatssicherheitsdienstes der ehemaligen Deutschen Demokratischen Republik (BStU), informally known as the Gauck Institute.

\section{CURRENT AIMS OF FRG INTELLIGENCE}

Contemporary FRG intelligence is directed and controlled by the BND, with the posts in Pullach and Berlin. The aim of intelligence and analytical activities conducted by the FRG Intelligence Services is two-fold. First, it collects information necessary to pursue foreign policies. Second, it has to ensure national security and maintain the survival of the state. ${ }^{36}$ Nowadays, the BND cooperates with other Intelligence Services both from Europe and from the USA, especially with a mutual aim to fight terrorism and to prevent the proliferation of weapons of mass destruction. It has to be mentioned that the terrorist phenomenon was used in the period of the Cold War to destabilise the FRG. Both Soviet and East German Intelligence Services inspired, offered financial and material support, gave shelter and carried out training for various extreme leftist terrorists, e.g. from RAF. ${ }^{37}$ At the turn of the $21^{\text {st }}$ century, a major threat the BND has to face comes from Islamic terrorist groups and some international extreme rightists, e.g. Combat 18 or Blood and Honour, connected with the groups operating in the FRG. One cannot forget, however, about a basic function of the Intelligence Services which is es-

35 See: K. MaCrakis, Seduced by Secrets. Inside the Stasi's Spy-Tech World, Cambridge 2008.

36 See: official BND webpage (a short introduction of BND main mission and aims) http://www.bnd.bund.de/cln_117/nn_1435078/EN/WirUeberUns/WirUeberUns_node.html?_nnn $=$ true $(26.05 .2012)$.

37 See: J. Herf, An Age of Murder: Ideology and Terror in Germany, https://www.telospress.com/main/pub/Herf_Telos144.pdf (26.09.2012). 
pionage and political intelligence. A permanent object of the BND's focus is, quite possibly, Poland, alike other countries which border Germany. The operations carried out in Poland can include various fields of political, military and economic activity, due to close relations between the two countries. Many organizations and foundations can be useful for German intelligence in a process of collecting intelligence data. Contemporary German intelligence is able, as it has already proven by the example of Reinhard Gehlen, to make use of intelligence backroom connected with the East German Intelligence Services. Undoubtedly, every more significant FRG post in the world, also in Poland, has to be filled with standard intelligence residents, whose responsibilities and tasks concern the fields of HUMINT, SIGINT or TECHINT.

Nowadays, the BfV Counter-intelligence Services, apart from a basic conducting and ensuring counter-intelligence security procedures, attach great weight to dangers whose origin lies in a development of many forms of radicalism in the FRG. Separate departments have been specially designed to deal with leftist and rightist radicalism, possible subversive activities carried out by foreigners, and problem of Islamic terrorist attacks. It has to be emphasised though, that it is the FRG which has become a place to collect funds and potential candidates to carry out terrorist attacks for Al-Quaeda and other associated organizations. It cannot be ruled out, however, that many more direct attempts at terrorist attacks will finally hit the FRG if the state's participation e.g. in the war in Afghanistan grows. The BfV has to fulfill a difficult task of providing counter-intelligence security and safety, due to a rise in activity of the Russian and Chinese Intelligence Services. ${ }^{38}$ Russian intelligence, which has a vast experience of operating on the German territory, quite possibly aims at collecting information about the fields important for the Russian Federation policies - vide mutual activities concerning energy policies and the so-called activities of an agent of influence. Many European Counter-intelligence Services have already signaled an increased activity of the Russian intelligence in Europe. Yet another significant threat for the BfV to cope with is an activity of the Chinese intelligence. In $21^{\text {st }}$ century, a special meaning has been attached to Chinese industry intelligence, concentrated on collecting data concerning technological solutions which has been adopted by the German industry. Needless to say, that Germany has become the biggest partner of dynamically developing China.

$$
* * *
$$

An experience which stems from the observation of the activities of the Intelligence Services operating on the German territory indicate, that every state in the world, which is a contact point for possible confrontation of stronger subjects, becomes an object of focus for many Intelligence Services. Therefore, it is important to, apart from developing partner relations with other countries, strive for the best possible protection of the country's own interest. This should be achieved both on an intelligence and counter-intelligence level. Most importantly, a country must not let a period of financial or staff weakness to happen. What is more, it is vital to always maintain a motivation level of intelligence and counter-intelligence agents and analysts as high as possible. Even

38 See: A. Knight, Szpiedzy bez maski. Spadkobiercy KGB, Warszawa 2001. 
during periods of the so-called relaxation trend in the international situation, a special importance has to be attached to ensure security of the crucial political and economic national institutions. What is more, foreign infiltration has to be counteracted by all possible means. A case similar in character to this of Günther Guillaume can not only destabilise state machinery even in fixed democratic conditions, but also pose a country to a threat of great financial loss. To conclude, Germany is no more a basic front country in contemporary intelligence wars but has remained an aim of some intelligence operations. At the same time, contemporary German Intelligence Services have become an active and powerful tool of their country. Together with a rise of international position and an extension of German interest, whole Europe have been observing a grow in intelligence security measures aimed at supporting state's activities. However, the most demanding challenge for contemporary German Intelligence Services is to fight terrorism, which is especially difficult to trace in a open and multicultural society.

\begin{abstract}
After 1945 the most important everyday mission performed on the border between the cold and the hot war was, however, the one fulfilled by forces which belonged to a less visible but still extremely important formation - namely the Intelligence Services, Counter-intelligence Services and, above all, their agents and analysts. While a cold-war tension was rising and the two German states were built, a territory of the current Federal Republic of Germany turned into one of the biggest fronts of world espionage. An experience which stems from the observation of the activities of the Intelligence Services operating on the German territory indicate, that every state in the world, which is a contact point for possible confrontation of stronger subjects, becomes an object of focus for many Intelligence Services. Therefore, it is important to, apart from developing partner relations with other countries, strive for the best possible protection of the country's own interest.
\end{abstract}

\title{
NIEMCY PO 1945 ROKU \\ - KLUCZOWY FRONT ZIMNOWOJENNEGO STARCIA SLUŻB SPECJALNYCH
}

\section{STRESZCZENIE}

Po zakończeniu II wojny światowej, na najbardziej widocznym pograniczu zimnej wojny, dzielącym Europę na dwie części, najważniejszą, codzienną misję pełniły siły należące do formacji mniej rozpoznawalnych od wielkich jednostek wojskowych, ale niezmiernie ważnej - mianowicie wywiady, kontrwywiady, a przede wszystkim ich poszczególni agenci oraz analitycy. Wraz z narastaniem napięcia zimnowojennego oraz budową dwóch państw niemieckich, terytorium obecnej Republiki Federalnej Niemiec, przerodziło się w jeden z największych dotychczasowych frontów światowego szpiegostwa. Doświadczenia płynące z obserwacji działań wywiadów na terytorium Niemiec wskazują, że każde państwo świata, leżące na styku potencjalnej konfrontacji silniejszych podmiotów, staje się obiektem zainteresowania różnych służb wywiadowczych. Dlatego też, należy w sposób szczególny oprócz, oczywiście rozwijania partnerstwa z innymi państwami, dążyć do jak najlepszego zabezpieczenia własnych interesów również na płaszczyźnie wywiadowczej oraz zbudowania przede wszystkim skutecznego własnego zabezpieczenia kontrwywiadowczego. 